Entertainment

\title{
Doctors in the movies
}

\section{G Flores}

\section{Healers, heels, and Hollywood}

$\mathrm{T}$ he world continues to have a passion for movies. Moviegoers worldwide spent $\$ 20.3$ billion and purchased 8.6 billion admission tickets to see films in 2003. ${ }^{1} 2002$ was a record breaking year at the UK box office, with 176 million cinema admissions, £755 million in total box office receipts, and 369 films released. ${ }^{2}$ In the USA in 2003, there were 1.6 billion cinema admissions, $\$ 9.5$ billion in box office receipts, 473 films released, and home entertainment sales to dealers of 1.1 billion DVDs and 294 million video cassettes. ${ }^{3}$

Movies have a powerful influence on popular culture, due to their international popularity, easy accessibility, and profitability as an industry. Cinematic depictions of doctors thus have the potential to affect public expectations and the doctor-patient relationship. In a 2002 paper, I conducted an in-depth analysis of the portrayal of doctors in the movies, reviewing 131 films from nine countries spanning eight decades. ${ }^{4}$ Key findings from this research included: (1) compassion and idealism were common in early doctor movie portrayals but have become increasingly scarce in recent decades; (2) since the 1960s, positive doctor portrayals declined while negative portrayals increased; (3) doctors frequently are depicted as greedy, egotistical, uncaring, and unethical, especially in recent films; (4) a recurrent theme is the "mad scientist", the doctor-researcher who values research more than patients' welfare; (5) because negative portrayals of doctors are on the rise, patients' expectation and the doctor-patient relationship may be adversely affected; and (6) films about doctors can serve as useful gauges of public opinion and tools for medical education. The aim of this paper is to use this extensive database, supplemented by several more recent films, to explore selected key themes about the portrayal of doctors in the movies. In contrast to the prior paper, however, this paper will also focus on humour in doctor films (both intentional and unintentional), and examine the few movies that have portrayed paediatricians.

\section{MAJOR THEMES IN DOCTOR MOVIES \\ Money and materialism}

Materialism and a love of money have pervaded cinematic portrayals of doctors dating back to the 1920s, and continue to be prominent in recent movies. In Doctor at Sea (1956), Dr Simon Sparrow (Dirk Bogarde) states, "A Rolls Royce is the ambition of almost every newly qualified doctor. And preferably a Harley Street address to go with it." In Carry on Again Doctor (1969), Dr Jim Nookey (Kenneth Williams) confides to a colleague: "Specialise, that's what I'd like to do! The whole Harley Street bit with bags of lovely filthy rich women patients." In Doctor at Large (1957), the doctor in charge of a Harley Street practice advises Dr Sparrow, "You know, it's a chastening thought, but good clothes are more important to a GP than a good stethoscope."

Indeed, it shocks and bewilders other characters when movie doctors do not display adequate wealth. In Playing God (1996), an FBI agent visits the home of the surgeon Dr Eugene Sands (David Duchovny) to arrest him for the death of

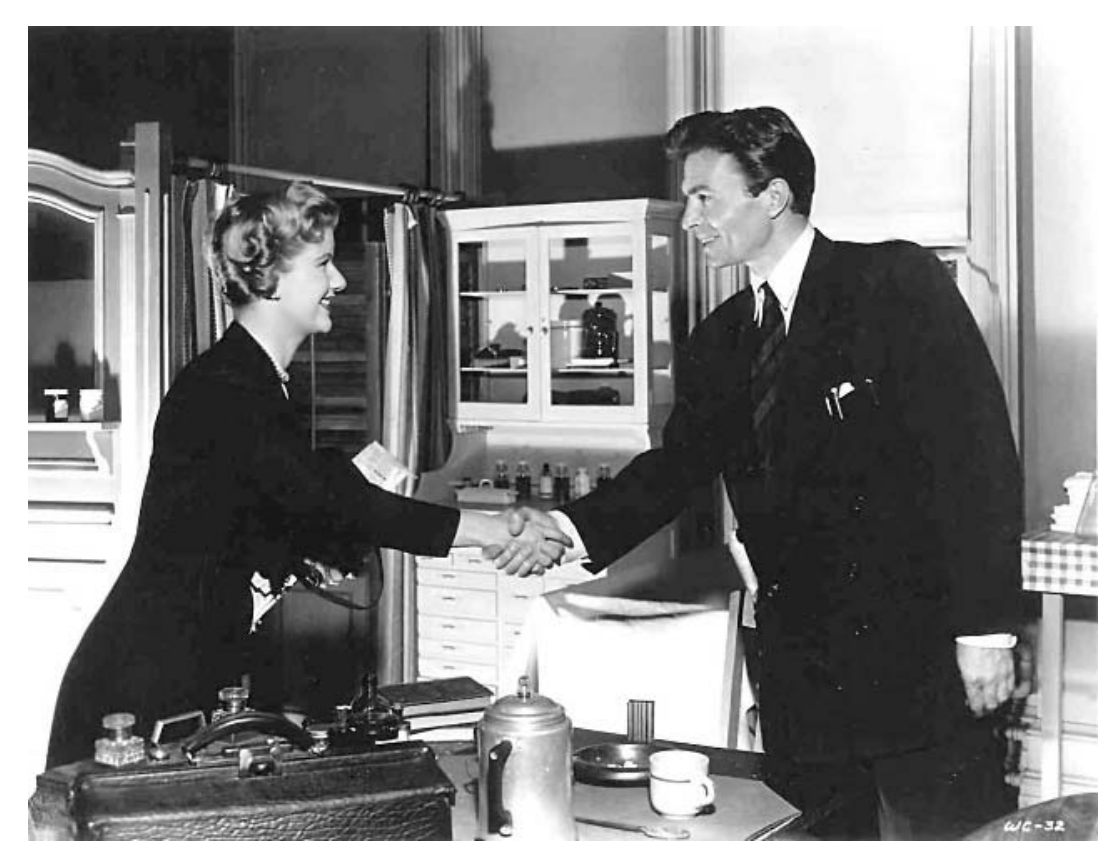

Figure 1 Paediatrician Dr Larry Quinada (James Mason) in Caught (1949). Reproduced courtesy of the Academy of Motion Picture Arts and Sciences.

a patient due to operating while addicted to drugs, and the agent says, "This is not how a doctor lives. No, this is squalor. I mean, you did go to medical school, right?" Dr Sands replies, "What, are you going to arrest me for failing to live up to my potential?".

Money is not infrequently portrayed as the prime motivation for becoming a doctor and choosing a medical specialty. In Not As a Stranger (1955), medical school classmates discuss their career options:

\footnotetext{
"Personally, I'm for surgery. I just got a look at Dr Dietrich's car. You know what he drives? A Bentley. $\$ 17,000$ bucks."

"That guy doesn't take out a splinter for less than \$1000."

"I'll still take ear, nose, and throat.

The common cold is still the doctor's best friend."

"Call it a virus. You make more dough that way."

"Look, if you kiddies are all through, your old man here will really wise you up. It's not what you practice, it's where."

"What do you mean?"

"I've done a little research on this problem. The average doctor's income is $11 \mathrm{Gs}$. In the southwest, west, and more..."

"Pebble Beach, Colorado Springs, Beverly Hills, that's where the rich are crackin' up fast."
}

Movie doctors even base treatment decisions on patients' ability to pay. In Critical Care (1997), Dr Werner Ernst 


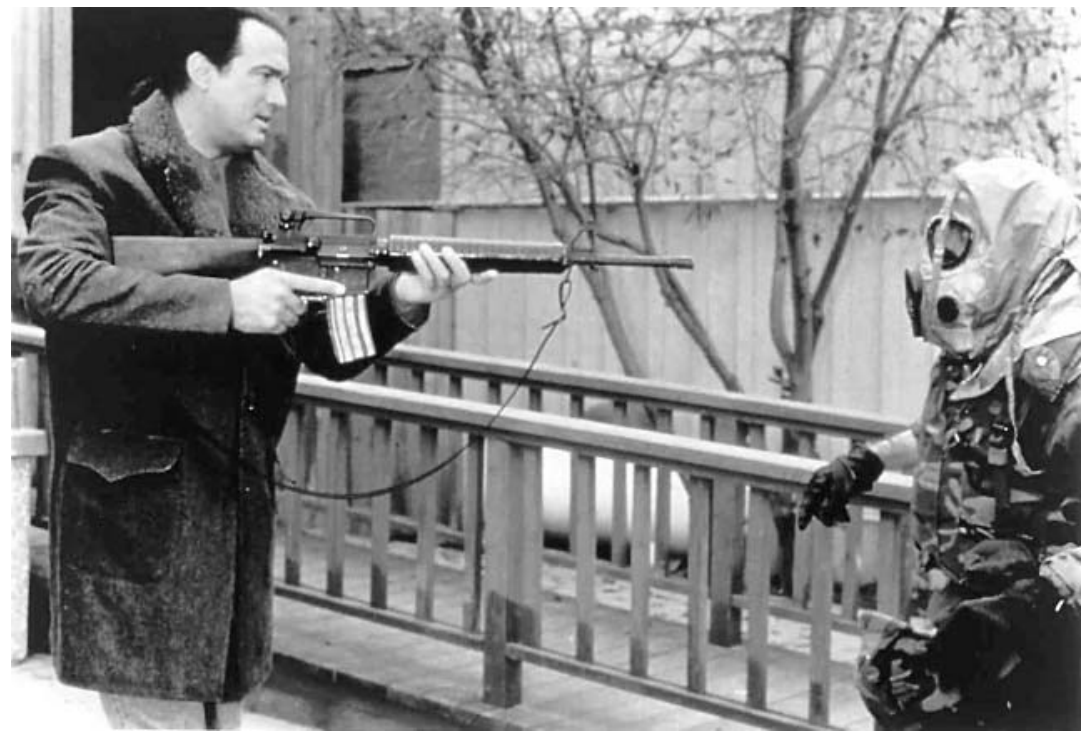

Figure 2 Dr R Wesley McLaren (Steven Seagal) confronts a paramilitary extremist in The Patriot (1998). Reproduced courtesy of the Academy of Motion Picture Arts and Sciences.

(James Spader), in the intensive care unit (ICU), asks "ICU Chairman Emeritus" Dr Butz (Albert Brooks) why a comatose patient with a poor prognosis needs a procedure:

"If there's no reasonable prospect of cure, why should we proceed?"

"Where have you been all your life: It's called revenue! He's got catastrophic health insurance. Long term health care. The works!"

"What difference does his insurance make?"

"What? It's cash money. Not one of those 'try and collect from the estate' deals. And you want to yank his tubes!"

\section{Paediatricians}

The medical specialty of movie doctors most often is surgery (33\%), psychiatry $(26 \%)$, or family/general practice ( $18 \%)$, with paediatrics accounting for only $2 \% .{ }^{4}$ It is informative to examine movies with a paediatrician as the main character. Every Girl Should be Married (1948) was released with fanfare as RKO's big Christmas offering, and was a financial success. ${ }^{5}$ Anabel Sims (Betsy Drake), a romantic woman determined to find the perfect husband, meets and falls in love with handsome paediatrician Dr Madison Brown (Cary Grant) when they both reach for a copy of "Better Babies" at a luncheonette. He resists her obvious advances, and she uses every trick and trap, including a fake romance with her department store boss, to finally land Dr Brown. In real life, Drake and Grant met in 1947 aboard the luxury liner Queen Mary travelling from England to the USA, and were married one year after the film's release (Drake was Grant's third wife and the marriage lasted almost 13 years, the longest of Grant's five marriages). ${ }^{5}$

Dr Brown is portrayed as a compassionate, dedicated paediatrician who sometimes does not even charge for patient visits. Brown playfully scolds a mother of three who happily departs

"Now before you bring these youngsters of yours in here again, after a clinic visit:

Norma, make sure there's something the matter with them so that I can send you a bill."

"You probably will anyway."

"Heh, heh."

"Come along boys, we'll get no sympathy here."

Brown twice comments on the long hours he puts in as a paediatrician. After putting in a particularly long day, he says to his nurse, "Oh my, why didn't I become a night watchman or a flagpole sitter or somebody with regular hours instead of a baby doctor." After Brown's cocktails with Anabel are interrupted by a call from a concerned mother, he says, "I'm sorry, Annabel, but that's what it's like being a doctor, no time for anything else", to which she replies, "but I think being a doctor is the most wonderful thing in the world a man can be!" Brown delivers a lecture to mothers entitled, "The Parent's Responsibility to the Child. A Lecture by the Eminent Pediatrician Madison W Brown, $\mathrm{MD}^{\prime \prime}$. His concluding remark is impressive for revealing an insight privy to the experienced paediatrician: "However, there is an instinctive wisdom in most mothers which transcends all the science of doctors."

In Caught (1949), Leonora Eames (Barbara Bel Geddes) fulfils her dream by marrying millionaire Smith Ohlrig (Robert Ryan), but the marriage is a disaster, so she goes to work in the office of paediatrician Larry Quinada (James Mason), who has devoted his

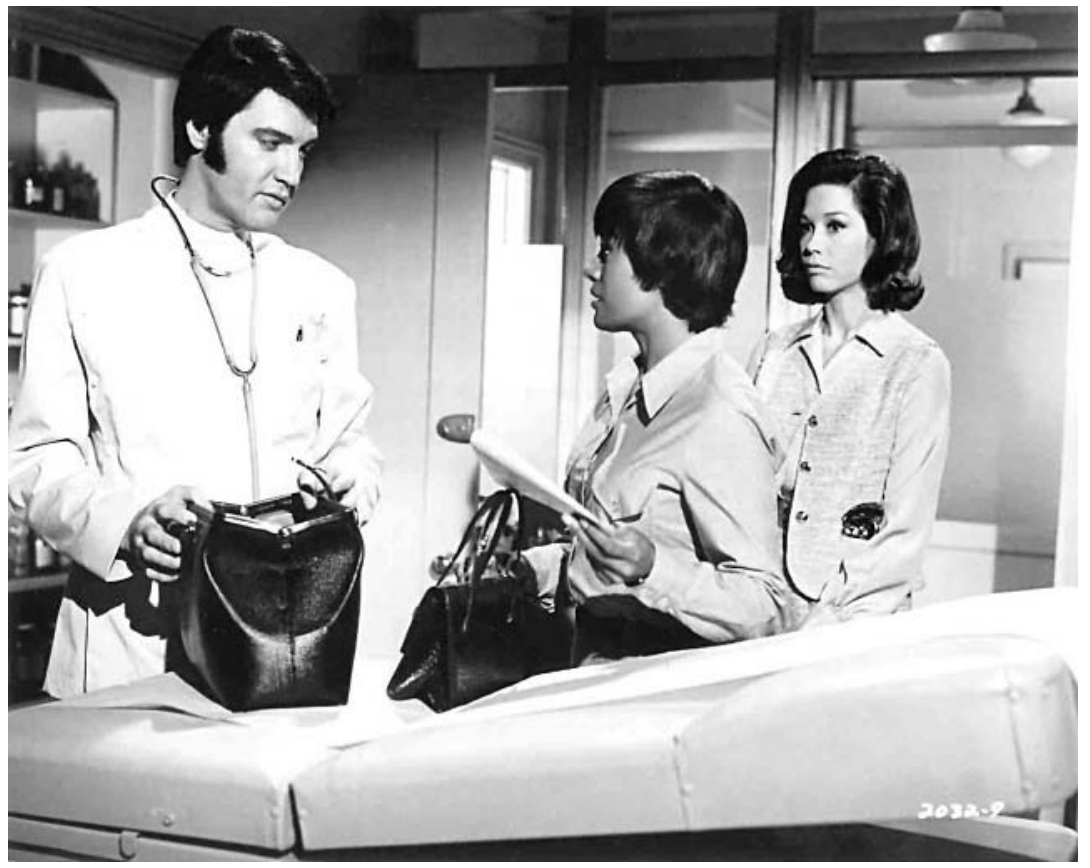

Figure 3 Dr John Carpenter (Elvis Presley) speaks to Sister Irene Hawkins (centre, played by Barbara McNair) and Sister Michelle Gallagher (Mary Tyler Moore) in Change of Habit (1969). Reproduced courtesy of the Academy of Motion Picture Arts and Sciences. 
life to serving impoverished children in New York City (fig 1). They fall in love, but Eames is pregnant with Ohlrig's child, which she finally miscarries, and then Eames and Quinada live happily ever after. The portrayal of Dr Quinada is noteworthy for his commitment to the under-served and lack of interest in materialism. Eames's interview with Quinada proceeds as follows:

\footnotetext{
"You know what the job is, Miss Eames?"

"Receptionist."

"Yes, for Dr Hoffman and me. He's an obstetrician, I'm a paediatrician."

"He brings children into the world, I try to keep them here."

"I'm sure you succeed, doctor."

"Well, I don't always. It's easier to write prescriptions than to pay for them."
}

Later, when Eames has become Quinada's receptionist and lover, she comments on his attitude to money:
"That's because you don't care about money."

"Everyone's got to care about money to a certain extent-how else can I take you out to dinner when I want to. But I care more about other things like doing the kind of work that interests me."

"Is that why you work on the East Side?"

"Sure. I can learn more there in one day than I can learn anywhere else in one month."

After this brief burst of paediatrician movies, little attention has been paid to paediatricians as main characters. In Sunchaser (1996), which does not feature a paediatrician, a 16 year old with a retroperitoneal sarcoma who is imprisoned for murdering his stepfather is referred to adult oncologist Michael Reynolds (Woody Harrelson), whom he later kidnaps. Angered that a paediatrician will not treat the patient because he is a murderer, Reynolds says, "Paediatrics can't just dump their overload on us. Tell them to cut down on their lunchtime and tennis. Maybe they'll have more time to practice medicine." The Wedding Planner (2001) features Dr Steve Edison (Matthew McConaughey) as a paediatrician who is engaged to another woman but eventually calls off the marriage because he has fallen in love with his wedding planner, Mary Fiore (Jennifer Lopez). This maudlin, forgettable film is noteworthy for Edison inexplicably hospitalising the adult Fiore on a paediatric ward and using a paediatric cervical collar after Fiore suffers a concussion and loss of consciousness, and for Edison mentioning that he had to attend a diverticulitis seminar, a conference of doubtful utility to a paediatrician.

\section{Bureaucracy and healthcare systems}

Movie doctors frequently face the frustrations and follies of having to confront inefficient bureaucracies and healthcare systems that hinder patient care. In Article 99 (1991), Dr Sturgiss (Ray Liotta) explains to an intern why openheart surgery is being performed on a patient admitted for prostate surgery:
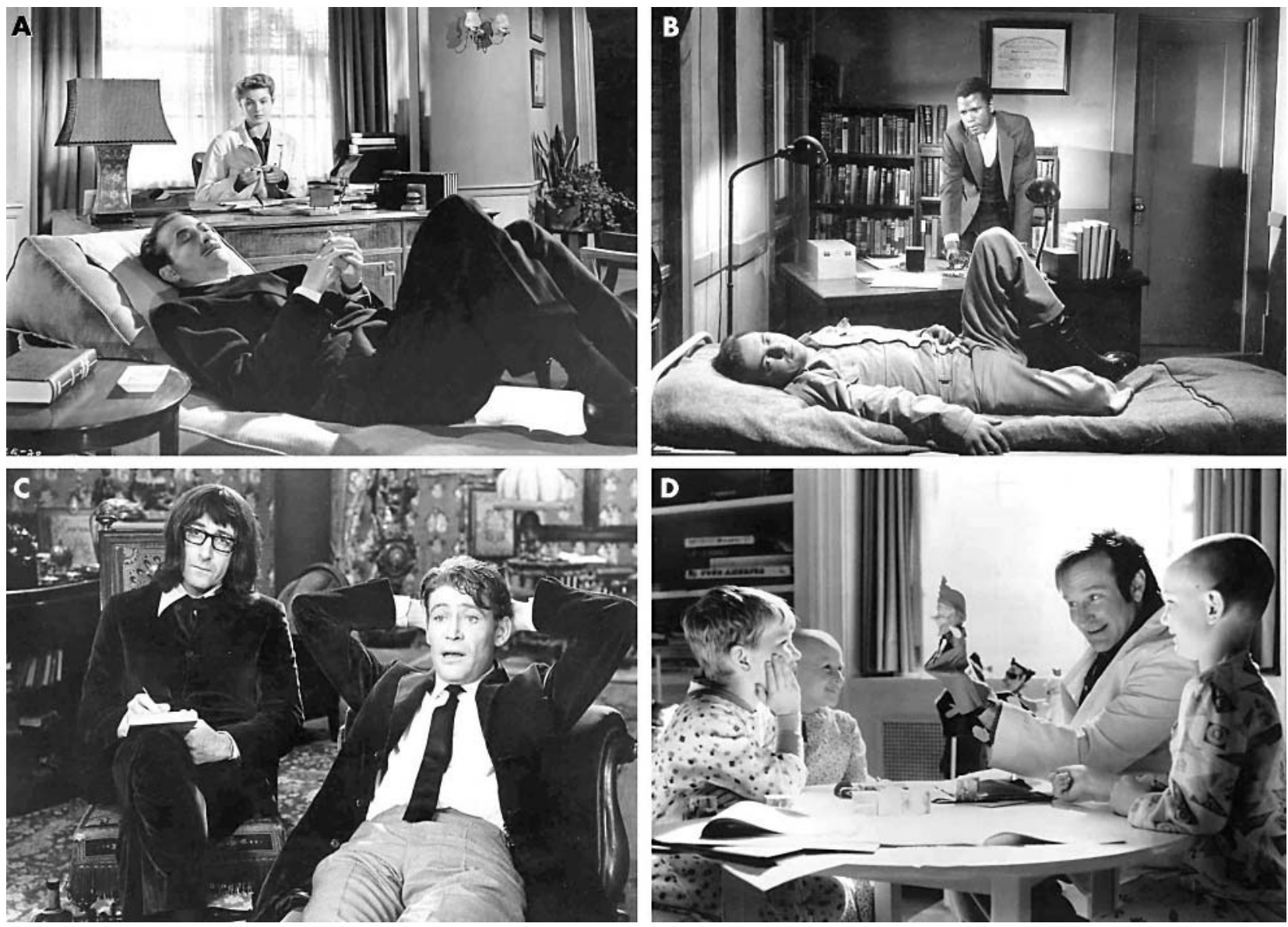

Figure 4 (A) Dr Constance Peterson (Ingrid Bergman) psychoanalyses a patient in Spellbound (1945). (B) Prison psychiatrist (Sidney Poitier) treats a racist Nazi psychopath prisoner (Bobby Darin) in Pressure Point (1962). (C) Dr Fritz Fassbinder (Peter Sellers) in What's New, Pussycat (1965) takes notes on his patient, Michael James (Peter O'Toole). (D) Dr Patch Adams (Robin Williams) plays with paediatric patients in Patch Adams (1998). All photographs reproduced courtesy of the Academy of Motion Picture Arts and Sciences. 
Table 1 Annotated "top-ten" lists: doctor movies the author considers the best, most humorous, and most useful in medical education

Best
1. Red Beard (1965)
Arrogant young man in 19th century Japan
destined to be Shogun's doctor learns true
meaning of being a doctor from senior mentor
who cares for poor (Toshiro Mifune). Directed
by Akira Kurosawa.
2. The Hospital (1971)
Searing examination of chaotic urban hospital
and doctor (played by George C Scott) pushed
to the edge. Won American and British
Academy Awards for Best Screenplay (Paddy
Chayefsky).

\section{Article 99 (1991)}

Doctors in Veterans Hospital try to care for patients despite bureaucracy and stingy administrator.

4. State of Emergency (1993)

Jaded emergency room doctor (Joe Mantegna) struggles to care for patients as he battles budget cutbacks, overcrowding, and takeover by an $\mathrm{HMO}$.

\section{Miss Evers' Boys (1997)}

Compelling drama about infamous Tuskeegee Study of untreated syphilis in AfricanAmericans. Made-for-TV movie won five Emmys and nominated for another seven.

6. The Elephant Man (1980)

Biography of John Merrick (John Hurt) and his compassionate physician (Anthony Hopkins) Directed by David Lynch, Hurt won British

Academy Award for Best Actor.

7. Panic in the Streets (1950)

Dr Clint Reed (Richard Widmark), a Public

Health Service doctor, determines an immigrant

killed by hoodlums had pneumonic plague, and to prevent a catastrophic epidemic, must track down killers aided by reluctant police chief. Won Academy Award for Best Story

8. Spellbound (1945)

Hitchcock classic about psychiatrist (Ingrid Bergman) who helps amnesiac accused of murder (Gregory Peck) uncover his past.

\section{Death and the Maiden (1994)} Torture/rape victim (Sigourney Weaver) confronts her doctor torturer (Ben Kingsley) in this adaptation of a play directed by Roman Polanski.

10. Guess Who's Coming to Dinner (1967) African-American tropical medicine specialist (Poitier) brought home by fiancée (Katharine Houghton) to meet her parents (Spencer Tracy and Katharine Hepburn) shock and test parents with their interracial romance. Academy Awards

for Best Actress and Screenplay and British Academy Awards for Best Actor and Actress. psychiatrist (Peter Sellers) who has problems of his

\section{Malice (1993)}

Most humorous (intentionally and unintentionally)

1. $M^{*} A^{*} S^{*} H(1970)$

Three surgeons in Korean war save lives, goof around and engage in sexual antics. Directed by Robert

Altman, film won numerous awards and spawned TV series.

\section{Body Parts (1991)}

Unethical surgeon-researcher transplants various

body parts, with (unintentionally) amusing

consequences. Don't miss classic line, "Can't you see this arm is killing me!"

3. High Anxiety (1977).

Dr Richard Thorndyke (Mel Brooks), new Director of Psychoneurotic Institute for the Very, VERY Nervous, is framed for murder in this parody of Hitchcock movies.

4. The Patriot (1999)

\section{Most useful in medical education}

\section{The Doctor (1991)}

A hotshot surgeon with a detached demeanour learns about empathy and compassion when he contracts cancer. Based on autobiographical book by Ed Rosenbaum.

\section{Arrowsmith (1932)}

From the Sinclair Lewis novel, film deftly explores a doctor's motivations and struggles with clinical versus research career, and thus inspirational and enlightening for medical students. Nominated for four Academy Awards and Directed by John Ford.

\section{The Citadel (1938)}

Young, idealistic doctor (Robert Donat) becomes disillusioned after practicing in Welsh mining town, is corrupted by lucrative practice for London hypochondriacs, and needs major shock to appreciate true meaning of being a good doctor. From AJ Cronin novel; nominated for four Academy Awards.

\section{Not As a Stranger (1955)}

Follows lives of several medical students, examining such issues as career choices, greed, and racism. Star studded cast includes Robert Mitchum, Frank Sinatra, and Lee Marvin as doctors.

American cowboy, and martial arts expert. He single handedly conquers extremist paramilitaries and the most lethal viral outbreak ever.

5. What About Bob (1977)

Multi-phobic patient (Bill Murray) follows nationally renowned psychiatrist (Richard Dreyfus) on vacation, turning his life upside-down.

5. Pressure Point (1962)

Excellent examination of racial issues in which Sidney Poitier plays a prison psychiatrist forced to treat a racist Nazi prisoner (Bobby Darin).

6. Carry on Doctor (1968)

Among the most famous in the "Carry On" series, filled with many gags (but not much of a plot).

\section{Doctor at Sea (1956).}

To escape romantic entanglement, Dr Sparrow (Dirk Bogarde) becomes ship's doctor, getting involved with passenger (Brigitte Bardot) and madcap shore adventures. British Academy Award Nominee: Best British Screenplay.

\section{What's New, Pussycat (1965)}

Engaged philanderer (Peter O'Toole) seeks aid of own. Woody Allen's first film as both actor and director; features Oscar nominated song of same name.

\section{Torture Ship (1939)}

Research doctor who believes he has isolated "endocrine glands for criminality" recruits six homicidal criminals to be research subjects on board ship in exchange for passage to new country. Based on a Jack London short story, most humorous moments feature horribly coercive "informed consent" for research.

Otherwise predictable thriller with nice plot twist, noteworthy for amusing soliloquy by surgeon Jed Hill (Alec Baldwin) featuring, "You ask me if I have a God complex? Let me tell you something: I am God." 
"Here's the problem: this patient needs open-heart surgery. The administration of this hospital will only authorise a prostate procedure. Now what good is fixing his prostate if he has a heart attack every time he tries to use it?" In Extreme Measures (1996), a hospital administrator confronts resident Dr Guy Luthan (Hugh Grant) about the costs of multiple lab tests on a patient who died mysteriously:

"Who the hell is Claude Menkins?"
"It's 'was.' I'm afraid he died."
"Tell me he had insurance."
"No. That's not at all likely."
"This is $\$ 2600$ worth of lab work."
"Right. Could I..." [Reaches for
printout].
[Snatches back printout]. "I had two
people tied up for eight hours."
"Well, you know, Gene, what you
do in the privacy of your own home
is really your business."
"O.K. Let's get it into your head.
This is not England. This is not the
National Royal Shakespeare tax-
payers pick up the tab health care
system. O.K. Somebody has to pay
for this s---!"

Humour: intended and unintended In Body Parts (1991), psychologist Bill Chrushank (Jeff Fahey) loses his arm in a car accident, but receives an "arm transplant" by Dr Agatha Webb (Lindsay Duncan), who is transplanting body parts harvested from convicted killers. After Chrushank recovers, he finds that his "killer's arm" has a life of its own, forcing him to strike his wife and murder the surgeon and anaesthesiologist who performed his operation. Chrushank sets out to discover other recipients of transplants from the donor, who it turns out was a serial killer. The serial killer's head is transplanted onto someone else's body, and the killer starts slaughtering each transplant recipient to get back his body parts. Chrushank eventually kills the resurrected serial killer. Perhaps the most humorous segment of the film is when Chrushank asks Dr Webb to detach his rogue arm transplant:

"Do you realise what I and my team
have accomplished with that arm of
yours? Don't you realise that if a
gun were put to my head I wouldn't
jeopardise the accomplishments that
your surgery represents?"
"Can't you see this arm is killing
me!"
"I'm sorry to put this so bluntly, Bill,
but the pain you're in just isn't that
important when I balance it against
the significance of the experiment."

"You won't perform the operation to remove the arm?"

"No. And I'll see you put in a mental institution before I let you undo what I've done."

When you need a doctor who "really kicks butt", R Wesley McLaren, PhD, MD (Steven Seagal) is your man (fig 2). In The Patriot (1998), McLaren heads up the Montana Wellness Center, specialising in family practice and holistic therapy. In addition, he is a Native American cowboy, single father, and former world famous government immunologist. When a paramilitary extremist releases a "highly contagious viral agent" called NAM 37 that has " 10 times the potency of anthrax", McLaren must develop a "cure" and fight extremists in hand-to-hand combat and with firearms. Among the more unintentionally humorous segments are McLaren diagnosing a patient with "severe oedema of the abdomen and liver" before palpating the patient's abdomen, using a light microscope to examine the virus, developing a treatment for the virus in an evening's work which almost instantly cures patients, and McLaren killing the paramilitary chief with the stem of a wineglass, then doing a flip through a plate glass window, holding his rescued daughter wrapped in a blanket. The "cure" is derived from a traditional Native American herbal therapy, and consists of a tea or injection of a red flower distillate. A whole army troop is shown collecting red flowers in biohazard gear, and the entire community is saved when US Army helicopters shower the town with red flower petals, which inhabitants are instructed to use to treat themselves with cups of tea.

In Change of Habit (1969), Elvis Presley plays Dr John Carpenter, a musically talented general practitioner who runs a free clinic in a tough section of New York City (fig 3). Dr Carpenter is in the middle of a jam session with community youths when he is called away:

\section{"Hey Doc! You left us hanging in the middle of our thing, man." \\ "Just fake it for about 32 bars. I'll be right back." \\ "You're the doctor?" \\ "You don't look like a doctor." \\ "Well, man doesn't live by bread alone. Especially the kind of bread you make working at the free clinic. John Carpenter, MD. Just like the sign says."}

Three nuns who also are healthcare professionals covertly are assigned as laypersons to Carpenter's clinic on a religious mission, including Sister
Michelle (Mary Tyler Moore), a social worker and speech therapist. Michelle falls in love with Carpenter, but does not allow the relationship to start, and returns to her convent conflicted. She attends a community church where Carpenter is leading a musical mass, and the movie ends with Michelle trying to decide between God and the god-like musician-doctor Elvis Presley, a difficult choice indeed.

\section{COMMENT}

Doctor movies continue to fascinate because they can be humorous, thought provoking, informative of the public's perception of doctors, and they never cease to entertain. Movie doctors provide insightful and realistic portraits of the challenges, rewards, and excitement of being a doctor, whether it's Ingrid Bergman playing a psychiatrist in Alfred Hitchcock's Spellbound (1945), Sidney Poitier as a prison psychiatrist forced to treat a racist psychopath in Pressure Point (1962), Peter Sellers as the wacky psychiatrist in What's New Pussycat (1965), or Robin Williams as the physician-clown Patch Adams (1998) (fig 4). For the aficionado, I provide a series of annotated "top-ten lists" of doctor movies I consider to be the best, most humorous, and most useful in medical education (table 1 ).

\section{ACKNOWLEDGEMENTS}

I am very grateful to the Academy of Motion Picture Arts and Sciences for providing the outstanding movie stills, to Sarah Hallbauer for her assistance in preparing the manuscript, and to Alisa Flores for insights on the movies and manuscript.

Arch Dis Child 2004;89:1084-1088.

doi: 10.1136/adc.2003.048843

Correspondence to: $\operatorname{Dr} G$ Flores, Center for the Advancement of Urban Children, Department of Pediatrics, Medical College of Wisconsin 8701 Watertown Plank Rd, Milwaukee, WI 53226, USA; gflores@mail.mcw.edu

Supported in part by grants from the Robert Wood Johnson Foundation

All figures provided courtesy of the Academy of Motion Picture Arts and Sciences

\section{REFERENCES}

1 Motion Picture Association Worldwide Market Research. MPA snapshot report: 2003 international theatrical market. Encino, CA: MPA Worldwide Market Research, 2004.

2 UK Film Council. Film in the UK 2002. Statistical yearbook. London: UK Film Council, 2003. 3 Motion Picture Association Worldwide Market Research. U.S. entertainment industry: 2003 MPA market statistics. Encino, CA: MPA Worldwide Market Research, 2004

4 Flores G. Mad scientists, compassionate healers, and greedy egotists: the portrayal of physicians in the movies. J Nat Med Assoc 2002:94:635-58.

5 Turner Classic Movies. Every girl should be married. http://www.turnerclassicmovies.com/ ThisMonth/Article/

0,,76183\%7C76184\%7C76189,00.html. 


\section{How to assess your specialist registrar}

\section{H Davies, R Howells}

\section{Performance assessment requires careful thought and planning}

$\mathrm{T}$ his paper outlines the principles of good assessment, including the importance of defining the purpose of assessment as well as what should be assessed. It then considers how SpR assessment should be undertaken, including possible tools for assessment such as peer ratings, patient assessment mini-CEX, and portfolios. It concludes with a brief discussion of how to draw together the various aspects discussed and some advice on remediation.

There is a requirement for annual assessment of all specialist registrars (SpRs). ${ }^{1}$ However, this is undertaken on an ad hoc basis with wide variation in practice both between and within specialties. Little of the assessment undertaken to date has been sufficiently robust to withstand legal challenge. Annual assessment for SpRs is soon to be extended to SHOs through Modernising Medical Careers (MMC) and public, political, and professional pressure to show that adequate self regulation has been important in driving revalidation forward. A priority for the newly established Postgraduate Education Training and Standards Board (PMETB) has been to provide a principles and standards framework for assessment within postgraduate medical training $^{2}$ (box 1). Annual assessment for trainees will be used to show continuing fitness to practice within the revalidation framework. Assessment therefore is increasingly recognised as a priority; what remains unclear is how this should be done-how will we measure success?

The authors are part of a team responsible for implementing performance assessment for paediatricians in training on behalf of the RCPCH. This article provides guidance on good practice in relation to postgraduate assessment with particular reference to SpRs in paediatrics, although the principles discussed are generic in nature. Consensus and clarity regarding the purpose of assessment (why), the content of assessment (what), and the method of assessment (how) is essential. There is also a need for a clear framework to address problems for the minority of doctors whose assessment raises concerns about their ability to practice effectively.

\section{PRINCIPLES OF GOOD ASSESSMENT}

Key characteristics of assessment tools include reliability, validity, educational impact, feasibility, and cost effectiveness. The relative importance of these characteristics varies according to the purpose of the assessment.

\section{Reliability}

Reliability is a measure of reproducibility-would you get the same results if you administered the assessment again? Possible influences on reliability include differences between observers (interobserver reliability), variation within observers (intra-observer reliability), the nature of the test itself (test-retest reliability), and the nature of the problem itself (case specificity). Case specificity is a particular problem for clinical assessment of all types. It is important to realise that subjectivity and reliability are not incompatible. Subjective judgements, while not reliable on an individual basis may be reliable if sufficiently widely sampled. Within medical education, reliability is increasingly being evaluated using a technique based on analysis of variance; generalisability theory. ${ }^{3}$ By analysing components of variance it makes use of all the data to quantify known sources of error without multiple experiments. Identification of the sources of error is important as it allows sampling

\section{Box 1: PMETB assessment principles}

5. Assessments must provide relevant feedback they undertake to take place across the sources of error. It is also possible to mathematically model the circumstances that would be required (in terms of number of observations and numbers of independent observers) to achieve a given reliability. This means that it is possible to plan assessment in a way that ensures adequate reliability will be achieved. Conventionally a reliability coefficient of 0.8 is desirable for high stakes assessments such as certification procedures, although a lower reliability may be acceptable for widespread screening assessments.

\section{Validity}

Validity is a measure of how completely an assessment tool measures what it purports to. There are a number of different types of validity including construct, content, and criterion validity. ${ }^{4}$ Reliability is essential to the defensibility of an assessment-but demonstrated validity is also a fundamental requirement. It doesn't matter how reliable a test is, if it is not actually assessing the area of interest it is not worth using.

\section{Feasibility}

Evaluation of feasibility is essential. Assessment methods that are highly feasible on a small scale may prove very difficult to implement on a larger scale in a range of different settings. Consultants are already hard pressed and the time they have available to commit to assessment limited. Use of peers and patients for assessment as well as other health professionals is an important part of optimising feasibility.

\section{Educational impact}

Tools used should generate educational feedback that informs professional development planning. Because assessment drives learning, robust assessment which is seen to be valid and feasible

1. The assessment system must be fit for a range of purposes

2. The content of the assessment (sample of knowledge, skills, and attitudes) will be based on curricula for postgraduate training which themselves are referenced to all of the areas of Good Medical Practice

3. The methods used within the programme will be selected in the light of the purpose and content of that component of the assessment framework

4. The methods used to set standards for classification of the trainee's performance/competence must be transparent and in the public domain

6. Assessors/examiners will be recruited against criteria for performing the tasks

7. There will be lay input in the development of assessment

8. Documentation will be standardised and accessible nationally

9. There will be resources sufficient to support assessment 
is likely to have a greater educational impact and be more acceptable than one which is not. Tools which have low feasibility on a wide scale may be very useful in the context of remediation for doctors about whom there is concern.

\section{PURPOSE OF ASSESSMENT}

Fundamental to the development of any assessment process is clarifying the purpose of the assessment process. For trainees this means determining readiness to progress to the next stage of their training. The terms summative and formative are widely used to describe the difference between assessments which concentrate on making pass-fail judgements (summative) and those which concentrate on providing feedback on an individual's strengths and weaknesses (formative). Summative assessment may produce feedback which clarifies areas of concern or excellence for doctors, but it is not intrinsic to the process (as it is for a formative assessment process). Assessment is the most powerful stimulus to learning-we should use this strategically. By assessing the areas of practice that we consider to be the most important we will inevitably stimulate learning in these areas.

\section{WHAT SHOULD BE ASSESSED?}

Guidance on SpR annual assessment to inform the Record of In-Training Assessment (RITA) focuses on the assessment of practice, rather than knowledge. ${ }^{1}$ For doctors in practice there is a trend away from competence assessment towards performance assessment. Competence assessment is a measure of what a practitioner is capable of doing (the best he/she can do under controlled circumstances), whereas performance assessment is a measure of what he or she actually does in daily practice. ${ }^{5}$ Competence assessment does not necessarily predict performance. ${ }^{6}$ Miller provides a useful framework for conceptualising the difference between performance (does) and competence (shows how) ${ }^{7}$ (fig l). However, there continues to be confusion about the use of the terms competence and performance; workplace based assessment may be a better term as it avoids such confusion. Miller's pyramid also emphasises the fact that performance is built on a foundation of knowledge-without adequate knowledge it will not be possible to perform satisfactorily across a range of situations. Workplace based assessment provides an authentic representation of the way in which a doctor functions within a complex environment where there are many potential influences on their behaviour. Establishing assessment pro-

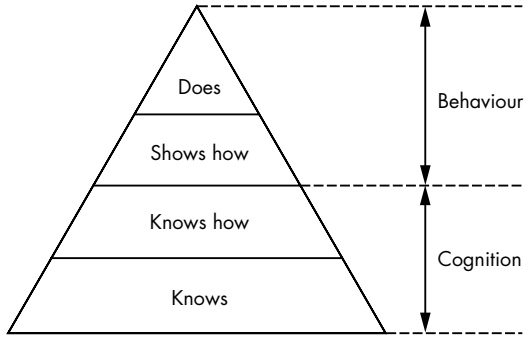

Figure 1 Miller's pyramid. ${ }^{7}$

cedures requires careful thought and a detailed and structured plan is necessary if this is to be done properly. ${ }^{8}$ There is currently a paucity of adequately evaluated performance assessment tools, and this is acknowledged worldwide. ${ }^{5}$ Tool development must be mapped to domains of competence, and guidance on these is available. ${ }^{5}$ Within the UK, Good Medical Practice (GMP) provides the framework for defining what a doctor is expected to be able to do. ${ }^{9}$ Mapping of SpR assessment to GMP will ensure that the requirements for revalidation are fulfilled by the process. Details of SpRs' practice profiles in terms of both the distribution of tasks (emergency versus outpatient work, for example) and relative frequency of different clinical problems are not, however, currently available.

\section{HOW SHOULD WE BE DOING SpR ASSESSMENT?}

The principles of how the development of a rigorous performance assessment programme for SpRs could be approached as well as illustrative discussion of some specific tools will be covered by discussion of how this problem has been approached within one, specific, postgraduate setting: annual assessment for paediatric SpRs in the UK.

Areas on which to focus initial efforts in relation to tool development have been informed by a range of sources (box 2). It is intended that all paediatric SpRs will be assessed using high feasibility "screening" tools such as peer ratings. ${ }^{10}{ }^{11}$ Where a potential problem is identified, more detailed assessment in the area of concern can be undertaken (fig 2). This is important both to ensure that a real problem exists in this area and to provide a detailed profile of the nature of the problem to inform planning of remediation.

Possible sources of evidence for performance assessment can be divided into two broad groups: generic and specific skills. Examples of possible tools in both groups are discussed.

\section{POTENTIAL TOOLS FOR PERFORMANCE (WORKPLACE BASED) ASSESSMENT Tools suitable for widespread screening (level 1, fig 2) \\ Peer ratings}

Peer ratings refer to judgements made by other health professionals about a doctor's performance. They are broadly equivalent to 360 feedback which has been used in industry for many years. They usually consist of a questionnaire with some sort of scale against which

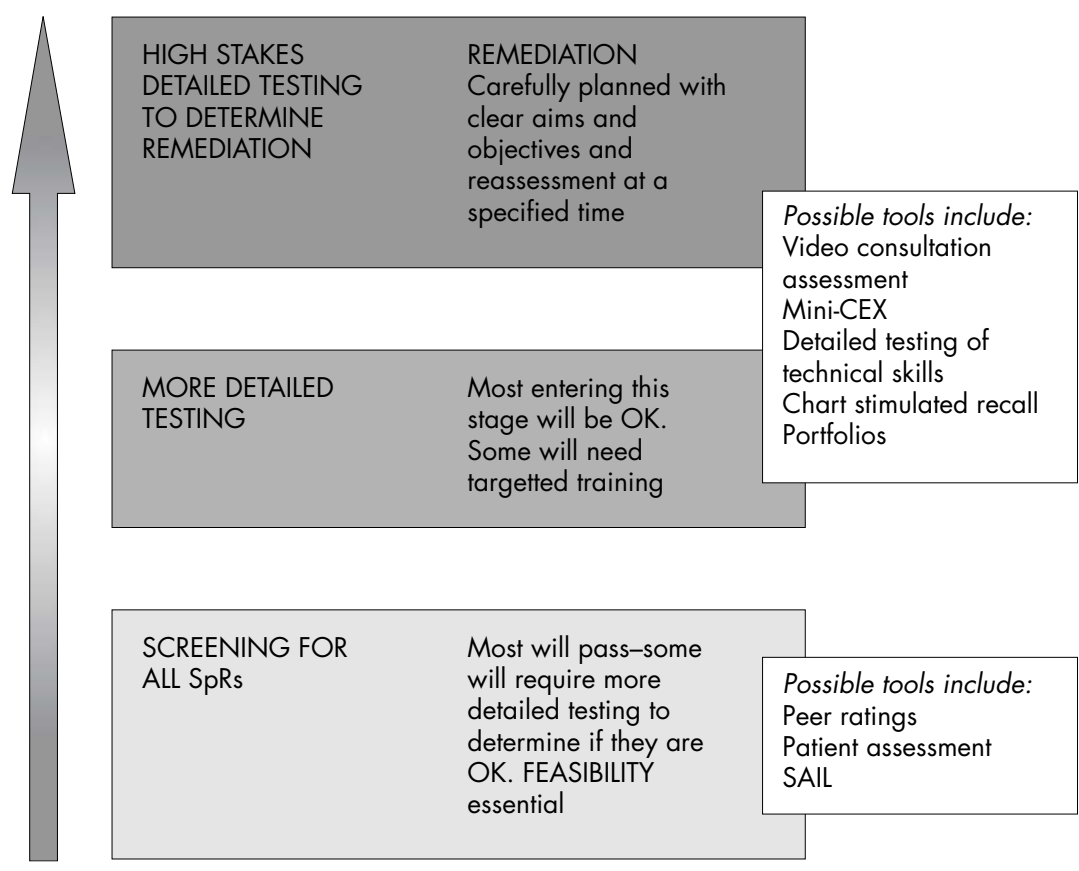

Figure 2 High feasibility screening tools are followed by more detailed testing in areas of concern to clarify problems and plan remediation where necessary. 
Box 2: Areas on which to focus initial efforts in relation to tool development for paediatric SpRs

These have been informed by a range of sources:

- Detailed review of performance assessment literature

- Areas recognised as being central to the practice of most physicians, in particular the consultation

- Good Medical Practice (GMP)9

- Agreed international domains for performance assessment (which map to GMP) $)^{5}$

- Areas recognised as being common areas of complaint/poor performance (communication and teamwork in particular)

- Consensus exercise with paediatric tutors identifying key features of an effective (paediatric) consultation

- Areas identified in GMC pilot for revalidation as being areas where doctors found it difficult to provide evidence of adequate performance (implying a deficiency of tools)-in particular, patient feedback and teamwork

- Areas where previous work suggests that performance assessment may be undertaken in a feasible, reliable way across a range of domains - in particular, peer ratings 1011

- Areas complementary to work being undertaken by the RCP, to avoid unnecessary duplication of effort

the doctor is judged in a number of areas. Peer rating is an attractive means of assessing a broad range of competencies for doctors in practice. It has huge potential as a high feasibility tool that is reliable and is able to assess areas that are otherwise difficult to assess, such as teamworking. Ramsey studied the clinical performance of physicians using written questionnaires mailed to professional associates of the physicians (both doctors and nurses). ${ }^{10}{ }^{11}$ Ramsey's questionnaire consists of 11 categories, and the rater is asked to score the physician in each category from 1 to 9 (or score UA if they feel unable to comment in a particular category). Eleven raters are needed to achieve a reliability coefficient of 0.7 .

Other workers have evaluated the use of peer ratings in different settings, mainly within the USA or Canadian healthcare system. ${ }^{12-14}$ In one of these studies $71 \%$ of surgeons followed up three months after administration of the instrument contemplated or initiated change on the basis of the multi-source feedback (based on self reporting). ${ }^{14}$

The GMC and PMETB advocate the use of peer ratings for work based assessment, and the RCPCH intends to utilise peer ratings as part of the standardised SpR assessment process. A peer assessment tool developed and evaluated with paediatric SpRs has been shown to have good reliability and validity in a pilot study. The tool consists of a 25 point questionnaire (Sheffield Peer Assessment Tool, SPRAT) mapped to GMP. For SpRs 11 raters across a range of health professionals are needed to achieve a reliability of 0.7 (generalisability analysis). SPRAT performs particularly well in the areas of team working and communication, areas which are traditionally difficult to assess. It is feasible and generates feedback which can be used to inform personal development planning (fig 3).

Performance assessment based on written records

Correspondence between

professionals

Correspondence between health professionals is an important record of a healthcare event. From April 2004 it will be mandatory to copy correspondence between professionals to patients/carers, and many doctors are already doing this. A validated tool for the assessment of outpatient correspondence has been developed (Sheffield Assessment Instrument for Letters, SAIL). It has been shown to have good reliability and feasibility, ${ }^{15}$ although further work is needed to determine how best to utilise SAIL in the context of widespread SpR assessment. Potentially other SpRs could be used as raters, which has high feasibility and good educational impact. A small pilot study has shown a significant improvement in letter writing following training with SAIL. ${ }^{16}$

\section{Patient and parent feedback}

Patients and/or their carers are ideally placed to provide feedback on how well a doctor communicates with them. A vast number of patient satisfaction tools are available. However, there has been almost no work undertaken which robustly evaluates how to use the patient's perspective as a defensible component of a rigorous assessment process, a problem highlighted by Sitzia in his review of patient satisfaction data. ${ }^{17}$ The American Board of Internal Medicine (ABIM) has done work to evaluate a patient assessment tool. ${ }^{18}$ A recent study of 351 paediatric consultations using the Sheffield Patient Assessment Tool (SHEFFPAT) has shown that 25 consultations are sufficient for parents' feedback to meet the criteria required for inclusion in a performance assessment programme (reliability of $>0.8$ evaluated using generalisability). ${ }^{19}$ Utilising patients/ carers not only meets criteria for performance assessment, but also fits well with the GMC and PMETB requirements and the concept of the expert patient.

\section{Tools better suited for more detailed testing (level 2, fig 2)}

Performance assessment based on written records

Written records

Medical records have huge potential for assessment, but ward based records may not represent the performance of the doctor making decisions (for example, an SpR or consultant ward round recorded by an SHO). ${ }^{20}$ Furthermore, assessment of the medical record alone does not allow an assessment of decision making/patient management skills as record keeping is simply too inconsistent. It may be important to assess an individual's ability to keep adequate written records, but this does not necessarily reflect their decision making skills. A potential way of using medical records to test more complex skills such as decision making, however, is through chart stimulated recall.

\section{Chart stimulated recall}

Chart stimulated recall (CSR) consists of assessment of performance through structured interviews, for which a selection of medical records from a physician's caseload acts as the focus. Assessment may be based on the quality of data acquisition, patient evaluation, the clinician's choices about patient management, and knowledge base. The GMC and College of Physicians and Surgeons of Ontario (CPSO) Canada incorporate CSR within their procedures for evaluating poorly performing doctors. Charts are reviewed by two assessors, and used as the focus for discussions with the physicians. Because case specificity (performance 


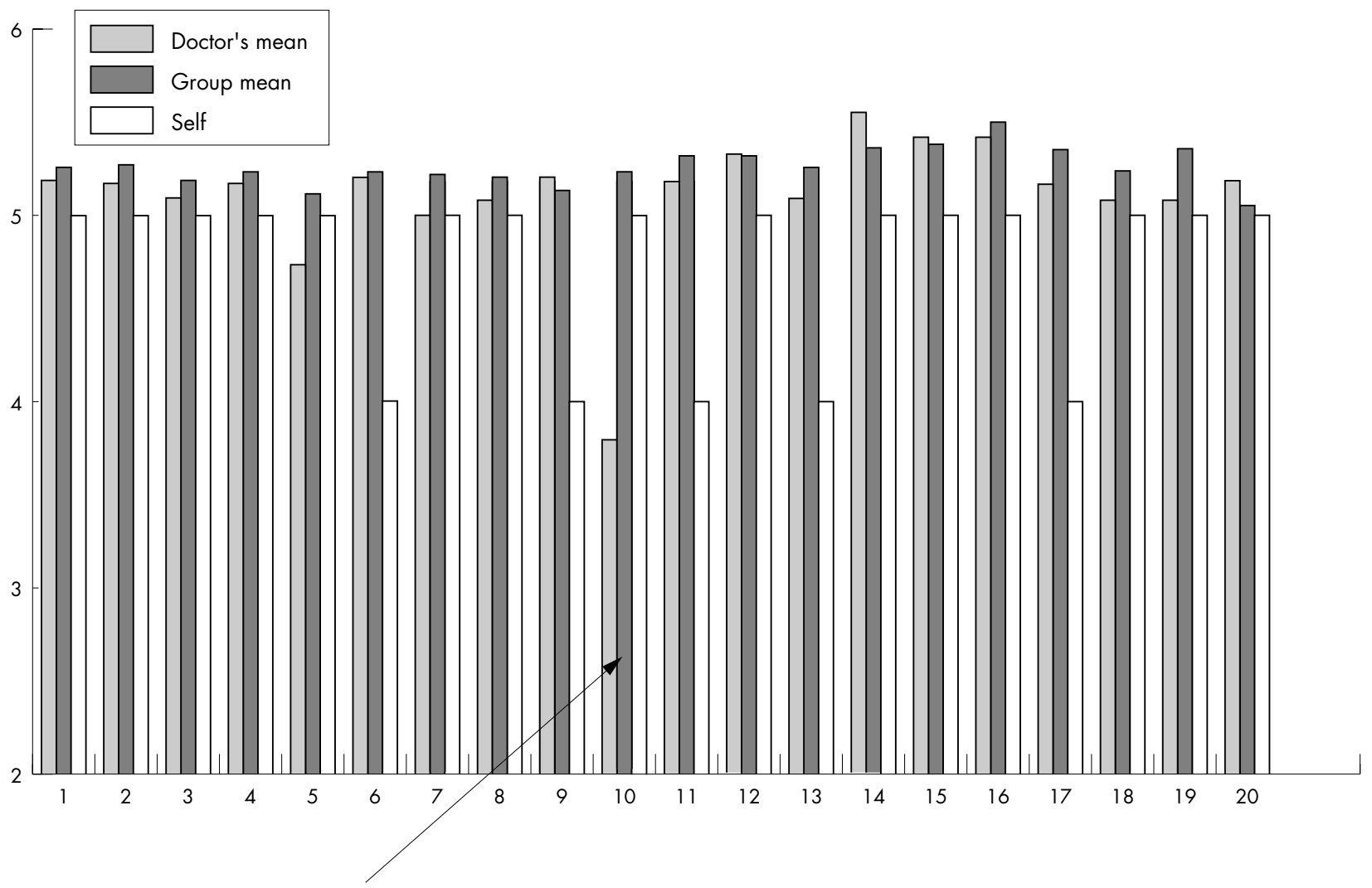

Question 10 asks the assessor to rate the doctor in relation to their ability to deal with stress, an area in which this doctor is performing less well than his/her peers and which could be a focus for development planning.

Figure 3 Example of feedback given to an individual doctor on the basis of peer ratings.

of an individual which is dependent on the nature of the medical case around which the interview is based) is a problem with this type of assessment tool, CSR interviews would need to be conducted on several occasions during training, in order to ensure that the method has adequate sampling validity.

Norman and Salvatoori have shown satisfactory reliability using CSR, and found it to be feasible. ${ }^{21} 22$ Data on the use of CSR in the UK setting for performance assessment are not available, but CSR has the potential to allow assessment areas which are otherwise very difficult to assess.

\section{Clinical and technical skills}

Although the assessment of communication, teamworking, and other generic skills is clearly essential, it is also important that core clinical skills are assessed. Possible tools available include mini-CEX. ${ }^{23}$ Mini-CEX is utilised by the ABIM to assess residents in training. Its aim is to assess residents' clinical skills, attitudes, and behaviours using a structured rating form completed by a senior member of faculty while observing a clinical encounter. It takes on average 20 minutes per encounter. Scores on the mini-CEX are influenced by the diffi- culty of the clinical case encountered as well as the nature of the problem. Wide sampling is essential and it is a method that is relatively time consuming for senior doctors, potentially limiting its feasibility. Work is being undertaken by the Royal College of Physicians to evaluate its measurement characteristics in a UK training grade setting. ${ }^{24}$

Assessment of core technical skills is clearly also important. A range of potential methodologies for doing this have been developed within the surgical specialties, and these could be modified for a paediatric setting. ${ }^{25}$ The use of video also has potential for the assessment of technical skills. ${ }^{26}$

Video has also been used for the assessment of consultation skills, most widely within a primary care setting within the UK, and also in the Netherlands and Australia. ${ }^{27-29}$ This has tremendous potential for providing structured feedback that can inform personal development planning for doctors. Pilot work is underway evaluating a paediatric consultation assessment tool based around existing models of the consultation. It may be appropriate, however, that the use of video for assessment purposes is reserved for those doctors who appear to have difficulty in the area of communication identified by higher feasibility screening tools such as patient assessment and peer rating. All trainees could, however, valuably be exposed to review of videos of their consultations as part of their training.

\section{Other skills}

Many other attributes and skills make up a doctor's practice and have not been discussed here. These include, for example, teaching and training, research skills, and critical appraisal. Portfolios offer potential as a means of assessing a doctor's overall professional profile, including these aspects of practice, as well as, importantly, an individual's ability to learn from experience. However, while their usefulness as a means of supporting professional development is widely acknowledged, their role in performance assessment is controversial. ${ }^{30}$

\section{Putting it all together}

None of these individual assessments on their own will be sufficient. In order to obtain a representative picture of a doctor's overall practice, a number of assessments sampling widely across the doctor's practice will be essential. These should be planned well in advance, and 
the nature and timing of the assessment processes made explicit to the trainees being assessed as well as to the assessors.

Training for assessors is essential and is likely to improve the reliability of the process. The nature and purpose of the assessments and the criteria against which judgements are being made should be made explicit to all participants. Quality assurance processes must be built into the process and should evaluate reliability and validity as well as ensuring that the overall assessment programme is in line with the PMETB assessment standards framework. ${ }^{2}$

Detailed assessment should be undertaken of possible problem areas identified by screening tools such as peer ratings.

\section{Remediation: principles and planning the process}

Remediation should be offered to all doctors about whom significant concern in any area of their practice has been raised, and adequate (or otherwise) remediation confirmed by appropriate assessment processes. Ideally each $\mathrm{SpR}$ and SHO programme should have an individual who is responsible for remediation. A written, individualised, framework should be produced in line with a nationally agreed outline framework for remediation. Additionally, it is of particular importance that an attempt is made to measure an individual's degree of insight into areas of concern as this may significantly affect the success of a remediation programme. Tools to assess insight are not yet well developed, but it is recognised as being a priority area for performance assessment development. ${ }^{31}$

\section{CONCLUSIONS}

Appropriate rigorous assessment of doctors is a challenge. Development and implementation of performance assessment requires careful thought and planning and a considerable investment of resources, both time and money. However, such investment is essential. Assessment is not only mandatory, it is the most powerful stimulus to learning. We should ensure that it is undertaken rigorously, but also that we assess not simply what is easiest, but what is most important, so that assessment has a real influence on doctors' practice and hence the quality of care they provide for patients.

\section{ACKNOWLEDGEMENTS}

Special thanks are extended to Dr Vin Diwakar for his thoughtful comments and input. Thanks also are due to Dr Julian Archer, Dr Jim Crossley, and Miss Judith Ellis

Arch Dis Child 2004;89:1089-1093.

doi: 10.1136/adc.2003.043232

\section{Authors' affiliations}

H Davies, Sheffield Children's NHS Trust, RCPCH lead for Performance Assessment, Sheffield, UK

R Howells, RCPCH Education Fellow and Honorary Clinical Lecturer, University of Cambridge, Department of Paediatrics, Cambridge, UK

Correspondence to: Dr H Davies, Consultant in Late Effects/Medical Education, Sheffield Children's NHS Trust, Western Bank, Sheffield S10 2TH, UK; h.davies@shef.ac.uk

Accepted 23 December 2003

\section{REFERENCES}

1 NHSE. A guide to specialist registrar training, NHSE, 1998.

2 Southgate L, Grant J. Principles and standards for an assessment system for postgraduate medical training, PMETB Subgroup on Assessment, 2003.

3 Crossley J, Davies H, Humphris G, et al. Generalisability: a key to unlock professional assessment. Med Educ 2002;36:972-8.

4 Jolly B. The good assessment guide: a practical guide to assessment and appraisal. London: Joint Centre for Education in Medicine, 1997.

5 Hays RB, Davies HA, Beard JD, et al. Selecting performance assessment methods for experienced physicians. Med Educ 2002;36:910-17.

6 Rethans J, Sturmans F, Drop R, et al. Does competence of general practitioners predict their performance? Comparison between examination setting and actual practice. BMJ 1991; 303:1377-80.

7 Miller GE. The assessment of clinical skills/ competence/performance. Acad Med 1990;6519 suppl):S63-7.

8 Schuwirth LW, Southgate L, Page GG, et al. When enough is enough: a conceptual basis for fair and defensible practice performance assessment. Med Educ 2002;36:925-30.

9 GMC. Good Medical Practice, GMC, 2001.

10 Ramsey PG, Wenrich MD. Peer ratings. An assessment tool whose time has come. J Gen Intern Med 1999;14:581-2.

11 Ramsey PG, Wenrich MD, Carline JD, et al. Use of peer ratings to evaluate physician performance. JAMA 1993;269:1655-60.

12 Rodgers KG, Manifold C. 360-degree feedback: possibilities for assessment of the ACGME core competencies for emergency medicine residents. Acad Emerg Med 2002;9:1300-4.

13 Violato C, Hall WG. Alberta Physician Achievement Review. CMAJ 2000;162:1803.

14 Violato C, Lockyer J, Fidler H. Multisource feedback: a method of assessing surgical practice. BMJ 2003;326:546-8.

15 Crossley GM, Howe A, Newble D, et al. Sheffield Assessment Instrument for Letters (SAIL): performance assessment using outpatient letters. Med Educ 2001;35:1115-24.

16 Fox A, Palmer R, Crossley J, et al. Improving the quality of outpatient clinic letters using the Sheffield Assessment Instrument for Letters (SAIL) Med Educ 2004;38:852-8.

17 Sitzia J. How valid and reliable are patient satisfaction data? An analysis of 195 studies. Int J Qual Health Care 1999; 11:319-28.

18 Webster GD. Final report on the Patient Satisfaction Questionnaire Project, American Board of Internal Medicine 1989.

19 Crossley J. Assessing the clinical performance of doctors. Thesis for Doctorate of Medicine, Oxford University, 2003.

20 Fernando KJ, Siriwardena AK. Standards of documentation of the surgeon-patient consultation in current surgical practice. Br J Surg 2001;88:309-12.

21 Norman GR, Davis DA, Lamb S, et al. Competency assessment of primary care physicians as part of a peer review program. JAMA 1993;270:1046-51.

22 Salvatori P, Baptiste S, Ward M. Development of a tool to measure clinical competence in occupational therapy: a pilot study? Can J Occup Ther 2000:67:51-60

23 Norcini JJ, Blank LL, Duffy FD, et al. The miniCEX: a method for assessing clinical skills. Ann Intern Med 2003; 138:476-81.

24 Wragg A, Wade W, Fuller G, et al. Assessing the performance of specialist registrars. Clin Med 2003;3:131-4.

25 Martin JA, Regehr G, Reznick R, et al. Objective structured assessment of technical skill (OSATS) for surgical residents. Br J Surg 1997;84:273-8.

26 Cronin C, Cheang S, Hlynka D, et al Videoconferencing can be used to assess neonatal resuscitation skills. Med Educ 2001;35:1013-23.

27 Campbell LM, Howie JG, Murray TS. Use of videotaped consultations in summative assessment of trainees in general practice. Br J Gen Pract 1995:45:137-41.

28 Ram P, Grol R, Rethans JJ, et al. Assessment of general practitioners by video observation of communicative and medical performance in daily practice: issues of validity, reliability and feasibility. Med Educ 1999:33:447-54.

29 Hays R, Spike N, Sen Gupta T, et al. A performance assessment module for experienced general practitioners. Med Educ 2002;36:258-60.

30 Wilkinson TJ, Challis M, Hobma SO, et al. The use of portfolios for assessment of the competence and performance of doctors in practice. Med Educ 2002;36:918-24.

31 Hays RB, Jolly BC, Caldon $\sqcup$, et al. Is insight important? measuring capacity to change performance. Med Educ 2002;36:965-71. 
Obstetrics

\section{Hindu birth customs}

\section{A R Gatrad, M Ray, A Sheikh}

\section{Marriage, pregnancy, and birth rituals}

$M$ any expectant mothers have fears and anxieties about their pregnancy. For Hindu pregnant women, these general concerns may be compounded by difficulties in communicating with healthcare professionals. It is our aim in this paper to provide clinicians with a basic understanding of Hindu birth customs in the hope that such appreciation will go some way to facilitating provision of culturally competent and sensitive care.

In their excellent paper Webb and Sergison $^{1}$ defined cultural competence as an evolving process that depends on self-reflection, self-awareness, and acceptance of differences. They further explain that such competence is based on improving understanding as opposed to an increase in cultural knowledge. While fully concurring with their views we would argue that knowledge of cultural context can be helpful in providing a prototype (as opposed to a stereotype) of factors which may be important in the provision of patient centred care.

Hinduism-one of the oldest world religions dating back to around 1500BC-originates from around the Indus Valley in what is now Pakistan. Scriptures were originally written in Sanskrit, a language in which most Hindus of today are no longer literate, and therefore customs over the years have tended to be passed on by word of mouth. Almost 14 centuries ago, many Hindus converted to Islam and 600 years ago Sikhism was founded as an "off shoot" of Hinduism. It is therefore unsurprising that not only have original Hindu customs been diluted over the years but that the practises of other religious customs found within South Asia have intertwined with remnants of Hindu teachings. However we have not encountered any consanguineous marriages among Hindus in the UK, a practice common among Muslims the world over. ${ }^{3}$

Hindus believe in a "transcendent" God who may be worshipped in a variety of ways through different symbolic manifestations (for example, statues). The three supreme Hindu deities forming the Hindu Trinity ${ }^{4}$ are: Brahma (The Creator), Vishnu (The Preserver), and Shiva (The Destroyer). In Britain, the majority of Hindus are Vishnuvites. ${ }^{5}$

Many Hindus believe that a person is born into a caste or acquires it by behaviour; ${ }^{6}$ for example, a person of a lower caste by being "pious" can go higher up the caste ladder. Although no longer officially recognised and less visible in modern India than in the past, the caste system still has a strong hold on Hindu families, and the impact of this on customs (including birth) also extends to those who have migrated. There are broadly four main castes: Brahmins (highest), Ksatriya (ruling caste), Vaisya (farmers and merchants), and sudras (the untouchables); this latter group usually work as servants in India.?

Closely linked with the caste system is the belief in reincarnation-a belief that one's deeds in a former life determine the caste that one is born into. This philosophy of $\mathrm{Karma}^{8}$ is of fundamental importance to Hindus, as, it is "deeds" in this world that will decide how the soul is reborn in the future. It is believed that this cycle of birth, death and rebirth ultimately results in attaining a state of purity that allows the liberated soul to become "at one" with the Divine presence.

\section{DEMOGRAPHIC CONSIDERATIONS}

The 2001 (UK) census revealed that there are over 559000 Hindus in Britain, ${ }^{9}$ the majority (467 000) of whom originate from the Indian subcontinent, with a sizable community coming from East Africa. This East African Hindu group is somewhat atypical in that it has undergone migration twice in a relatively short timeframefirst from India to East Africa and then on to Britain. In Britain, areas such as Harrow, Leicester, and Brent have significant Hindu communities making up $14-19 \%$ of the overall population (Office for National Statistics, 2003). Although generally religious, allegiance to religious customs will vary according to the extent of "acculturation" (whereby migrants take on some of the characteristics of the host community), and also on whether the family roots were in urban or rural India.

\section{BIRTH RITUALS AND THEIR} PRESENT DAY OBSERVANCE

The origins and performance of Hindu rites are not only somewhat complex but often also differ between castes. Here, we attempt to present some common features of these rites in order to help non-Hindu healthcare professionals to develop a working appreciation of these practices and their significance.

Manu, the legendary author of the Sanskrit Code of Law $^{10}$ created a number of sacraments or Samskaras - a word which means "perfection". These are "activities that help achieve 'purity' as a result of which the personality of the individual is developed to the full, from conception to the grave ${ }^{\prime \prime}{ }^{11}$ Each sacrament involves a prayer and often a ritual. Although only some of these sacraments relate to the present discussion of birth customs, for completeness and contextualising the principle, the first 10 of these that are relevant to the paediatric age group are described (table 1).

\section{MARRIAGE AND PREGNANCY}

The Hindu Marriage Act (1955) prohibited child marriages in India, stipulating that boys could only marry after the age of 18 years and girls after 15. Previously, early "child marriages" were thought by many to be a check on immorality and corruption. The introduction of this Act is believed to have contributed to a fall in maternal and infant mortality, while simultaneously improving the chances of the young to further their education before marriage. $^{12}$

Garbadhana-the fetus laying ceremony is performed at the consummation of marriage and involves special prayers for fulfilling parental duties to perpetuate the human race. In ancient times, the bridegroom did not approach the bride until the fourth night, but today this practice is only symbolically enacted at the marriage ceremony.

Punsavana-the "male making" rite is performed during the third month of pregnancy, in the belief that the "deity" governing the sex of the fetus is activated and a male "issue" assured. Sons are preferred because of the carriage of the family name and the hope that the son will light the funeral pyre of his parents. Manu says: "A man is perfect when he consists of three: himself, his wife, and his son". ${ }^{13}$ In fact, there is still a belief among many that in the next world/birth, the happiness of a father depends on having a continuous line of sons. ${ }^{14}$ Furthermore, birth of a girl, particularly in India, may generate parental anxieties because of the heavy financial burden resulting from the giving of dowries. 
Table 1 Hindu sacraments (Samskaras) relevant to children

\begin{tabular}{lll}
\hline Name & Procedure & Time when carried out \\
\hline Grabadhana & Sacrament of impregnation & Before pregnancy \\
Punsavana & Second/third month of pregnancy & Second/third month of pregnancy \\
Simantonnayana & Fifth to eighth month of pregnancy & Fifth to eighth month of pregnancy \\
Jatakarma & At birth & At birth \\
Namakarana & Naming the baby & $10-12$ days after birth \\
Nisramana & First outing of the child & Third/fourth month \\
Annaprassana & Weaning of the child & Sixth month \\
Chuda Karma & Cutting of hair & Occasionally at birth \\
& & Usually between first and third year \\
Karnavedha & Piercing of ears & Third to fifth year \\
Upanayana & Investiture of sacred thread & From eighth year, denoting the beginning \\
& & of manhood \\
\hline
\end{tabular}

Simmanantannaya-also known as Valaiakappu in some parts of India involves the wearing of red or green glass bangles from the seventh month of gestation. The sound of these bangles is believed to reach the womb and comfort the fetus. Traditionally, these are removed after birth and given to the midwife. Historically it is of interest to note that in this sacrament the mother is allowed to fulfil her last wishes, such as any craving for certain foods, as she is now thought to be entering a hazardous period..$^{15}$ A pregnant mother is therefore now expected to rest as much as possible. To this end, some women return to their parental home, even in the UK, only to return to the marital home 40 days after delivery. It may be that some patients miss their antenatal and postnatal appointments, partly as a result of this custom and the fact that clinics are often less accessible, with poor language support.

A study by Gatrad et al showed that there were significant differences in birth weight between five subgroups of South Asians. ${ }^{16}$ These groups were Muslim Pakistanis, Muslim Bangladeshis, Muslim Gujaratis, Sikhs, and Hindus. Although South Asian babies were generally lighter than the European, Hindus had the lightest babies at birth. It should be remembered that many Hindu women are often strict vegetarians and therefore do not eat eggs, fish, or meat which may, in addition to genetic and other environmental factors, partly explain the lower average birth weight of babies compared to other South Asian subgroups.

\section{BIRTH}

Our experiences suggest that, in common with other South Asian women, many Hindus prefer to be seen by female doctors during pregnancy and labour, on the grounds of modesty.

A premature birth in the eighth month of pregnancy is sometimes superstitiously attributed to a cat having entered the mother's room in a "former" confinement. It is believed by some that a child born in this month could die on the eighth day, in the eighth month, the eighth year, or the eighteenth year! Some Hindus therefore consider the number "eight" unlucky.

In India, when a male is born a Thali (a flat bronze utensil akin to a large tray) is beaten with a stick by friends and relatives. In the case of a girl, a fan, used for winnowing, is beaten.

Jatakarma-this ceremony welcomes the child into the family. The father touches and smells the child and whispers religious verses (Mantras) into the ears of the infant. All this is to promise the baby a safe and comfortable environment. To ward off evil, a small "dot" often in the shape of "Om" (see fig 1 ) is drawn behind the baby's ear using Kajal, a carbon based eye "make up".

This symbol may also be seen on a chain around a baby's neck or indeed be placed in a cot. A family member with "virtuous qualities" writes, with jaggery dipped in Ghee (a purified form of butter), the word "Om" onto the tongue of the neonate in the hope that the person's good qualities are passed on to the infant.

Symbolically, female members of the family wash a nursing mother's breasts

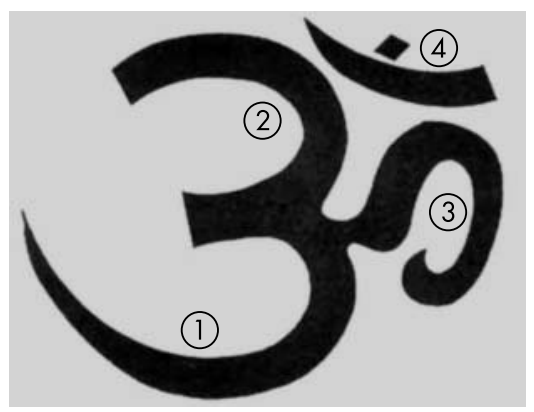

Figure 1 Om symbol. The most important Hindu symbol is Om; this has been described as "an Aksara or the 'Imperishable Symbol'; it is the Universe, the past, the present and the future-all that is and all that will be is Om; likewise all else that exists beyond the bounds of time-that too is $\mathrm{Om}^{\prime \prime} .{ }^{25}$ before breast feeding is commenced. We are aware of this practice in some Hindu families in Britain. The custom of not breast feeding the baby for the first two days is still rife in India, but in our experience this is not the case in Britain.

Certain foods are believed by many South Asians, including Hindus, to have either a "cooling" or a "heating" effect on the functions of various organs of the body, such as mood, personality, and physical wellbeing. ${ }^{17}$ Health professionals would therefore do well to be aware of the concept of "hot" and "cold" foods, both during pregnancy and the puerperium. For example, when the mother is breast feeding, if a baby has a cold or a fever, in the former case she may avoid "cold" foods and the converse when the baby has a raised temperature. This concept is quite divorced from the actual temperature of food or the intensity of taste of spices. High protein, acid, and salty foods are considered "hot", whereas "cold foods" are often sweet. Lentils, millet, aubergines, and grapes are examples of "hot" foods, and cereals, potatoes, milk, and white sugar are examples of "cold" foods.

Karnavedha-this refers to the ear piercing ceremony. Although usually carried out after the age of 3 years in most castes, there are some families where a father will not see the baby's face after birth until certain rituals have been performed, including ear piercing. Even the piercing of ears may be in the shape of Om. In India, a goldsmith performs this ritual for both sexes. Although girls often retain these holes, boys usually lose them in early childhood.

The sixth day after birth is considered the most auspicious in a person's life. On this day, a fragile white cotton thread is ceremoniously tied around the wrist, ankle or neck-this will usually spontaneously fall off a few days later. It is on the same sixth day that a pen and a blank piece of paper are placed in the baby's cot, as it is believed that on this day the goddess of learning charts the baby's future. The mother may observe a fast on this day.

Namakarana - the name is selected in such a way as to inspire the child to follow a righteous path. According to Hindu scriptures, a boy's name should have an "even" number of syllables and a girl's name an "odd" number. This custom is rarely followed in Britain, although in Indian villages it is still practised. There are several ways of naming a baby. ${ }^{18}$ One of the commonest, even in the west, is according to the Nakshatra or the sign of the Zodiac at the time of birth of the baby. It is believed that certain planets govern certain days, 
for example Mars governs Tuesday. If the Nakshatra for the time of birth is unfavourable, this may be a bad omen for the family necessitating certain rituals, which may include a special prayer and the father not seeing the baby for a few days. ${ }^{19}$ It is of interest to note that the documents, containing the horoscope of the baby, are admissible as legal papers of "proof of age" in India. ${ }^{20}$ Furthermore, the horoscope will be especially important for arranging a suitable marriage later. ${ }^{21}$

From the Nakshatra the first letter of the name is ascertained. For example, if it is a " $G$ " then the name could be Gyatri for a girl. The paternal aunt often plays an important part in the choice. Children may have a middle name such as "Devi" for a girl or "Lal" for a boy; for example, Gyatri Devi and Babu Lal. There are certain prohibited times for naming the baby; for example, at the time of an eclipse or when the signs of the Zodiac are changing. Hindu names have meanings; for example, Ravi for a boy means sun and Madhu for a girl means honey. Some boys are named after gods; for example, the names Krishna or Ram. Some girls may be named Chandra in the belief that the moon (Chand) will bring them luck and good fortune. Table 2 lists some common male and female Hindu names.

The naming ceremony takes place on the tenth or twelfth day after birth, a time when the mother is considered "clean" in order to carry out normal household chores, such as cooking. This custom is still practised by some Hindu families in the West. The nursing mother is now allowed male visitors.

Annaprassana-this ceremony takes place after six months when weaning is believed to be necessary for the baby to become more mobile. A delay in weaning that one occasionally encounters in Britain may be as a result of this belief. Although we have no evidence that Hindu babies in general are weaned at around four months in Britain, it is our experience that this is so.

Chuda Karma-the hair cutting ceremony (removal of scalp hair) is performed at any stage depending on family tradition, although according to the Samskara (table 1) it is performed between the first and the third year.

\section{DEATH OF A NEONATE OR INFANT}

At death, the baby is believed to leave the "earthly" realm into an "intermediate" zone in readiness for its journey to the "Divine realm". Although Hindus often prefer to die lying on the ground (Mother Earth), this custom is rarely practised for babies dying in Britain. Quality of palliative care, if indeed such care was necessary, has an impact on death and bereavement. ${ }^{22}$ Hindus who have perceived what they witness as a bad death, may be very anxious about the ghost of the deceased. ${ }^{23}$

As a baby approaches death, the family will chant "Ram Ram" or "Om" and recite from the Bhagavad Gita-the holy book for Hindus. A thread with a religious significance may be tied around the wrist or neck of the baby. Stillborns need the same religious "service" as adults. A leaf from a Tulsi shrub (basil leaf) is placed in the baby's mouth, occasionally with a gold coin. After a ritual wash, new clothes are put on the baby who is subsequently wrapped in a white shroud. The body of a baby may be taken from the hospital straight to the cemetery. However if the corpse is taken home, candles are lit and holy water from the River Ganges sprinkled onto the body.

Babies and young pre-pubertal children dying before the Upanayama stage are buried, whereas adults are cremated. Upanayama is the tenth sacrament and is a stage in a child's life when he/she begins adulthood after the age of 8 years. It is a stage ritualised by wearing a religious thread called Janeo. Children who die before this stage do not need purification by fire as they are classed as being "without $\sin ^{\prime}$. As a general rule,

Table 2 Examples of common Hindu names

\begin{tabular}{llll}
\hline Male & & & Female \\
\cline { 1 - 1 } Name & Meaning & Name & Meaning \\
\hline Abhijit & A constellation of stars & Anjali & Offering \\
Akaash & Sky & Anuradha & Bright star \\
Anand & Bliss & Priya & Loved one \\
Rajiv & Lotus flower & Priti & Satisfaction \\
Rohit & Red colour & Puja & Prayer \\
Ravi & Sun & Madhu & Honey \\
Sameer & Breeze & Madhur & Sweet \\
Deepak & Lamp & Meena & Precious stone \\
Mohan & Charming & Lakshmi & Consort of Vishnu \\
Harsh & Joy & Jaya & Victory \\
\hline
\end{tabular}


only nominally express allegiance and are not concerned with orthodox practice-this being especially true for those living in the West. Furthermore, religions are divided into different sects, resulting in individual adherents having their own particular view and interpretation of their faith and culture. Indeed, different generations within the same family may have differing views. Nonetheless, there are particular customs and rites, which tend to bind members of a religious community, and our experiences suggest that birth customs continue to be important to many Hindu communities, including those in Britain.

Arch Dis Child 2004;89:1094-1097. doi: 10.1136/adc.2004.050591

\section{Authors' affiliations}

A R Gatrad, Manor Hospital, Walsall, UK; Hon Professor Paediatrics University of Kentucky, USA

M Ray, Manor Hospital, Walsall, UK

A Sheikh, Division of Community Health

Sciences: GP Section, University of Edinburgh,

Edinburgh, UK
Correspondence to: $\operatorname{Dr}$ A R Gatrad, Manor Hospital, Moat Road, Walsall WS2 9PS, UK; sec.gatrad@walsallhospitals.nhs.uk

\section{REFERENCES}

1 Webb E, Sergison M. Evaluation of cultural competences and anti-racism training in child health. Arch Dis Child 2003;88:291-4.

2 Flood G. An introduction to Hinduism. Cambridge: Cambridge University Press, 1996:21.

3 Dhami S, Sheikh A. The family: predicament and promise. In: Sheikh A, Gatrad AR, eds. Caring for Muslim patients. Raddliffe, 2000:49.

4 Sharma A. Classical Hindu thought. Oxford: Oxford University Press, 2000:72.

5 Neuberger J. Caring for dying people of different faiths, 2nd edn. London: Moseby, 1994:24-9.

6 Lipner J. Voice of tradition caste and narrative. In: Hindu: the religious belief and practice. London: Routledge, 1994:108.

7 Joicey J. A handbook of Hinduism. Newcastle upon Tyne Education Committee, 1980:41.

8 Lipner J. Morality and the person. In: Hindu: the religious belief and practice. London: Routledge, 1994:233.

9 Office of National Statistics. Census 2001.

10 Pandey R. Hindu Samskaras. Delhi: MLBD, 1969: 17-24.

11 Singh C, Nath P. Hindu manners, customs and ceremonies. Delhi: Crest Publishing House, 1999:8.

12 Singh C, Nath P. Hindu manners, customs and ceremonies. Delhi: Crest Publishing House, 1999:31.
13 Singh C, Nath P. Hindu manners, customs and ceremonies. Delhi: Crest Publishing House, 1999:13.

14 Flood G. An introduction to Hinduism. Cambridge: Cambridge University Press, 1996:203.

15 Chaudhery NC. Religious control of Hindu life. London: Trinity Press, 1979:210-11.

16 Gatrad A, Birch N, Hughes M. Preschool weights and heights of Europeans and five subgroups of Asians in Britain. Arch Dis Child 1994:71:207-10.

17 Henley A. Asian patients in hospital and at home. London: Pitman, 1979:129.

18 Stutley M, Stutley J. A dictionary of Hinduism. Its mythology, folklore and development. London: Routledge, 1977:202

19 Singh C, Nath P. Hindu manners, customs and ceremonies. Delhi: Crest Publishing House, 1999: 128

20 Singh C, Nath P. Hindu manners, customs and ceremonies. Delhi: Crest Publishing House, 1999:142.

21 Shattuck C. Hinduism. Religions of the world. London: Routledge, 1999:81.

22 Koffman J, Higginson IJ. Accounts of carer's satisfaction with health care at the end of life: a comparison of first generation black Caribbean and white patients with advanced disease. Palliat Med 2001;15:337-45.

23 Firth S. Religious perspectives on end of life care: a Hindu patients spiritual and cultural values during the end of life period. Lancet. In press.

24 Schott J, Henley A. Culture, religion and childbearing in a multicultural society, Butterworth-Heinemann, 1996:311.

25 Rathakrishnan S. The Bhagavad Gita. Delhi: Harper Collins, 2000

Teenage pregnancy

$\mathrm{T}$ he rate of teenage pregnancy is higher in Britain than in other European countries Professional attitudes towards teenage pregnancy tend to be polarised with some considering it undesirable because of increased risks to mother and child while others have argued that teenagers may be well suited for pregnancy and that much harm comes from the stigmatisation of teenage parents. A study in Sweden (Petra Olausson and colleagues. British Journal of Obstetrics and Gynaecology 2004;111:793-9, see also commentary, ibid: 763-4) has shown that teenage mothers there are more likely to die young.

The study included 460343 women born between 1950 and 1964 and alive in December 1990. All had had a first child before the age of 30. Between 1990 and 1995, 1269 of these women died at ages 30-45 years. Mortality decreased with age at birth of first child from 107 deaths per 100000 person-years among women whose first child was born when they were 17 years or younger to 87 per 100000 person-years (first birth at 18-19 years), 54 (20-24 years ), and 42 (25-29 years). Overall, early adult mortality in teenage mothers was increased by $60 \%$ after adjustment for socioeconomic background at the time of the first birth and age in 1990. The main causes of premature death were violence, cervical cancer, coronary disease, lung cancer, suicide, and alcohol. Adjustment for socioeconomic factors operating after the birth of the first child reduced, but did not eliminate, the increase in risk.

Teenage mothers in Sweden have an increased risk of premature death in later life. Much of the increased risk is associated with adverse socioeconomic and lifestyle factors. The writer of the commentary argues in favour of helping teenagers to avoid pregnancy but also of providing adequate support for pregnant teenagers during and after their pregnancies. 